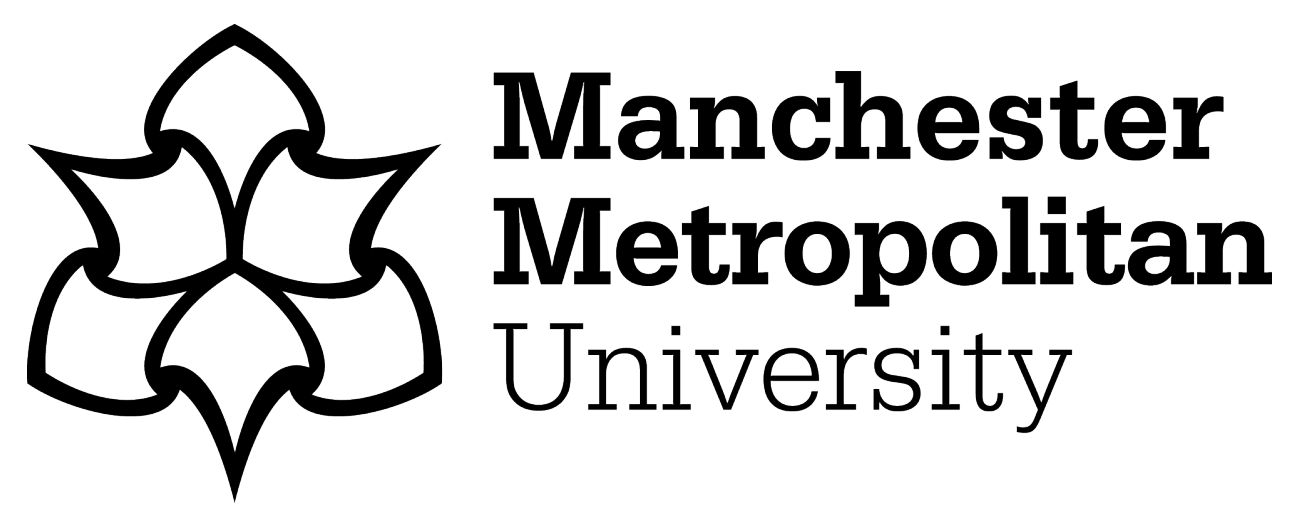

Medway, DJ and Warnaby, G (2018) Marketplace icons: shopping malls. Consumption Markets \& Culture, 21 (3). pp. 275-282. ISSN 1025-3866

Downloaded from: https://e-space.mmu.ac.uk/617217/

Version: Accepted Version

Publisher: Taylor \& Francis

DOI: https://doi.org/10.1080/10253866.2016.1231749

Please cite the published version 


\title{
Marketplace Icons: Shopping Malls
}

\author{
Gary Warnaby and Dominic Medway
}

This is a proof version of this accepted paper in Consumption Markets \& Culture. DOI information: http://dx.doi.org/10.1080/10253866.2016.1231749

\section{Abstract}

This article considers shopping malls as marketplace icons. We suggest that shopping malls can be regarded as a significant symbol of consumption in an age of late modernity, and highlight key aspects of their development. The role of the shopping mall as an agent of creative destruction, influencing the nature of the retail landscape (especially with regard to the implications of stereotypically suburban - malls for traditional urban retail provision), is discussed. We also consider the implications for notions of 'place' (in terms of authenticity and meaning etc.) arising from the fundamental characteristics of shopping malls, and end by suggesting that the shopping mall, as a marketplace icon, continues to dynamically and iteratively define and refine the ongoing interactions between consumers, the act of consumption, and place and space

Keywords: shopping mall, place, consumption, retail decentralisation

\section{Introduction}

In many ways, the shopping mall is an obvious candidate for inclusion in the 'marketplace icons' series. It is, at the most basic level, a marketplace, in that it constitutes an arena of commercial interaction in which retailers exchange tangible goods and services for consumers' cash, data and time. As for being 'iconic', some have identified the 'flagship' role that shopping malls can play in attracting shoppers to a particular locale (see for example, Dennis, Newman, and Marsland 2009; Smyth 1994). But the iconicity of the shopping mall arguably runs deeper than this, in that it became a symbol for a number of macro-level societal changes and associated consumption behaviours from the late 1950s onwards - initially in the US, and then the West, but latterly almost anywhere on the planet where there is a substantive urban population. Indeed, a recent list of the world's largest shopping malls identifies the top ten as being located in China (2), Iran (2), Malaysia (3), the Philippines (1), Thailand (1) and Turkey (1) (Said 2013); reflecting Jewel's (2001, 329) contention that "the image of the mall at its most universal level is that of a 'global product". 
Those societal changes and linked consumption behaviours contributing to the initial rise of the shopping mall in the US and the West included suburbanisation, the notion of the 'family car' and car-borne shopping trips, and the further development of practices popularised in pre-existing retail formats such as the $19^{\text {th }}$ Century department store, including shopping under one roof, one-stop shopping, the democratization of luxury, and the act of shopping as an experiential as well as functional activity (Nava 1996). In this respect the shopping mall can be regarded as a predominant symbol, if not the symbol, of consumption in an age of late modernity, in much the same way the department store became symbolic of new consumption modes and the beginning of shopping as 'being with things' in classical modernity and Hobsbawm's (1989) so-called 'long $19^{\text {th }}$ Century' from 1789-1914.

The terms 'shopping mall' and 'shopping centre' are regarded by many as synonyms. However, from a retail planning perspective, Guy $(1994, \mathrm{xvi})$ distinguishes between them by stating that the broader category of shopping centre consists of "a planned retail development comprising at least three shops, which is under one freehold ownership and managed and marketed as a unit", whereas shopping malls are a subset of this category, "usually comprising one or more anchor tenants and several smaller units, in one building or an architecturally unified group of buildings, and usually with a single ground landlord". Guy notes that the minimum size of a shopping mall is often defined as 100,000 sq. ft. of gross letting area; but of course many malls are much, much larger.

Shopping malls come in a variety of shapes and sizes, and Coleman (2006) identifies a range of criteria for their classification. These include: catchment (i.e. the size and geographical extent of the population served - regional, district, local etc.); location (with a fundamental dichotomy between in-town and out-of-town); tenant mix (which may be specifically geared to meet particular consumer demands); style of retailing (e.g. lifestyle centres, outlet centres etc.); physical form (e.g. an open or enclosed space); and combination with other uses (e.g. leisure, entertainment, commercial). Further, it is suggested that there are different mall variants based on location (see Coleman 2006): i.e. outof-town suburban shopping (including regional shopping centres, new town regional malls, and retail resorts etc.); and town centre shopping (including town centre malls, galleria and vertical malls, and speciality shopping etc.), and also identifies new emerging types, located in transportation hubs such as railway stations and airport concourses, as well as 'retail entertainment destinations' (which are integrated within the urban fabric of a town/city centre).

Whilst the genesis of the shopping mall is attributed to a period after World War II, the idea of shops, traders and consumers gathering together under one roof has a much longer history, stretching back the $1^{\text {st }}$ Century CE (Coleman 2006). It is a timeline that begins with forums in Ancient Rome (Carcopino 1991), and continues through the medieval market halls of Europe, and bazaars and souks of Turkey and other countries in the Middle East. In the case of the latter, Coleman notes that the Great Bazaar of Istanbul, established in 1461, represents the"[f]irst formally planned retail district of a town" $(2006,50)$. Later manifestations included the shopping arcades and passages of $18^{\text {th }}$ and $19^{\text {th }}$ Century Europe (see, MacKeith 1986; Geist 1989). The shopping mall, though, was an altogether different proposition to these predecessors, not least in terms of its scale. The idea of an enclosed area of shops with some associated parking space first appeared in the US as early as the 1920s, but building such developments large enough to draw people in from across a city region, rather than the immediate locale, began with architect Victor Gruen's Southdale Center. This opened in 1956 in the Minneapolis suburb of Edina, Minnesota. By pioneering the mall concept in 
what became such a popular form, Gladwell (2004) argues that Gruen may well have been "the most influential architect of the twentieth century".

Much has been written about shopping malls by academics across a variety of disciplines (see for example, Crawford 1992; Goss 1993, 1999; Jewell 2001). Indeed, there are so many studies of the West Edmonton Mall (see, for example, Shields 1989; Hopkins 1990, 1991; Butler 1991; Jackson 1991; Finn and Eidem 1995), North America's largest shopping mall, that it is easy to imagine it being more frequented by academics obtaining data than by shoppers seeking products. Space constraints preclude a detailed review of the rich and diverse literature on shopping malls here. Rather, and consistent with the title of this series, we will focus on the 'marketplace' and 'iconic' dimensions of shopping malls, with a specific emphasis on 'place' and the spatial implications of shopping malls as sites for consumption. The paper first considers the notion of malls as marketplaces, before moving to examine their role as creative destructors of the consumer marketplace, and finally the role of malls in creation of non-places in the consumption landscape, or 'blandscape' (to use Bonnet's 2014 term).

\section{Malls as marketplaces?}

The Oxford English Dictionary's definition of a marketplace is "an open space in a town where a market is or was formerly held"; an area typified by an attendant vitality of trade and vibrancy of people. In the 1950s, Gruen realised that shopping malls in the rapidly expanding US suburbs would need to capture some the energy of the urban marketplace. He was therefore motivated by a desire to provide the car-dependent population of suburban dwellers with some of the benefits and amenities of urban life. This was an envisioning of the shopping mall as "a place that not only provides suburbanites with their physical living requirements, but simultaneously serves their civic, cultural and social community needs" (Gruen 1960, 24). In this manner, Jewell indicates that Gruen's laudable intention was to "...create a focused and coherent centre within a sprawling and anonymous landscape" (2001, 319), and nowhere was this better evidenced than in Gruen's pioneering Southdale Center.

Earlier attempts at purpose-built shopping centres in the US had usually adopted an 'extroverted' design, with stores facing outwards onto a parking lot. Southdale, however, was 'introverted' in its layout, with the two storeys of 74 stores clustered around a central atrium, anchored at either end by competing department stores (Gladwell 2004). This was what became known as a classic 'dumbbell layout' (Jewell, 2001), encouraging a back-and-forth flow of pedestrians across mall space between these two key retail anchors, to the hopeful benefit of the smaller outlets that lay between them, and, thereby, attempting to mimic some of the vibrancy of the urban high street. Furthermore, beyond issues of layout, Southdale incorporated other key characteristics that captured various aspects of the shopping experience in the traditional urban high street by bringing some of the 'outside' in, including fountains, vegetation, live birds, sculpture, and even an 'outdoor' café in the mall atrium. (To grasp the impact of Southdale, see YouTube clip 1 2014; YouTube clip 2 2013).

Though seemingly revolutionary at the time, such experiential additions harked back to the original $19^{\text {th }}$ Century department stores as spaces of leisure and entertainment as well as commerce (Nava 
1996), and helped reinvigorate the notion of shopping as a pleasurable social pastime rather than a chore. As a marketplace, therefore, the success of Southdale delivered a blueprint that befitted and reflected a zeitgeist. Growing middle class affluence in post-World War II America required a site of consumption focus. Southdale, and the hundreds of suburban malls that replicated its spatial form and retail environment, fitted this brief perfectly, particularly from the 1960s onwards. Malls therefore fueled an American suburban dream, as captured in the Monkees' song Pleasant Valley Sunday, and satiated a resultant hunger for domestic appliances - 'a TV in every room' (Goffin and King 1967) and other goods for accessorizing suburban living. This latter point supports the latemodern notion of consumption as a means of identity formation, and the potential presentation and display of purchased items as a conspicuous declaration of that identity to others. Here, consumption is framed as a process of keeping up with the Joneses, or as Jackson and Thrift (1995, 208) so eloquently put it, "by our accoutrements shall you know us". In many ways, therefore, the shopping mall stood as a parenthetical symbol for such consumerist developments in society. It is noteworthy that filmic interpretations of this supposed suburban 'bliss' have sometimes been less positive, showing it to have a dark side of unneighbourly one-upmanship (as captured in Frank Perry's 1968 movie The Swimmer), and immoral excess, a fact highlighted in the stark contrasts between US suburban living and a war-torn Vietnam in Oliver Stone's 1993 film Heaven \& Earth.

By the end of the 1970s there were over 20,000 suburban shopping malls in the US (Oc and Tiesdell 1997), indicative of the format becoming a predominant feature of the retail and consumption landscape in the West. Indeed, by the mid-1980s, Kowinski claimed that the mall was not only a major economic force, but was also "becoming a way of life" for many $(1985,21)$, suggesting that "those born in the sixties and after, have never known a world without the world within the shopping mall" (ibid., 23). Thus, if department stores were described as the 'cathedrals of consumption' of the late $19^{\text {th }}$ and early $20^{\text {th }}$ Centuries (Crossick and Jaumain 1999), then from the mid- $20^{\text {th }}$ Century onwards this epithet could be applied equally to shopping malls, and in particular, to some of the more recently constructed 'mega-malls' across the globe. These would include, inter alia, the Golden Resources Mall, Bejing $\left(557,419 \mathrm{~m}^{2}\right)$, the Cehavir Mall, Istanbul $\left(420,000 \mathrm{~m}^{2}\right)$, the Mall of the Emirates in Dubai $\left(233,467 \mathrm{~m}^{2}\right)$, and the comparatively small Trafford Centre in Greater Manchester, UK $\left(207,000 \mathrm{~m}^{2}\right)$. Such developments blend retailing with leisure. Accordingly, cinemas, theatres, family entertainment centres, geographically themed areas, and even indoor skating rinks, ski slopes and rollercoasters can contribute to a hyper-real and arguably Disneyfied consumption experience. Liked or loathed, these attractions have allowed shopping malls to maintain their popularity as sites of consumption through an era of successful alternative retail formats, such as online shopping, sometimes to the point of being tourist attractions in their own right (Butler 1991; Gerlach and Janke 2001).

\section{The mall as a creative marketplace destructor}

As a retail format, we have established that the shopping mall has been an undeniable success, and undoubtedly worthy of the epithet 'marketplace icon'. But, echoing Schumpeter (1942), the history of shopping mall development as a force for marketplace creation, is also one of marketplace turbulence and destruction. This phenomenon is linked closely to the spatial dimensions of retail provision across urban areas. The dominant spatial narrative underpinning the development of 
shopping malls since the 1950s has been retail decentralisation (Schiller 1986). At the start it all made perfect sense; a suburbanising population needed access to good quality retail provision that avoided a problematic trip downtown to the retail heart of the central business district (CBD), where they would be subject to the challenges of increasing vehicular congestion, parking problems and exposure to the vagaries of the weather outdoors (Oc and Tiesdell 1991). Decentralising retailing away from the urban core to developments like Southdale (and its successors) provided an answer to such problems. In this respect, it was significant that the two original anchor department stores in the Southdale Center (Dayton's and Donaldson's) also had a nearby presence in downtown Minneapolis. Furthermore, the Dayton Company acted as the developer of Southdale, working together on the project with Gruen.

However, in the US especially, an answer, rapidly became the answer, and it was not long before the suburban 'Malling of America' (Kowinski 1985) was sucking the life out of traditional retail marketplaces in the heart of cities. Indeed, by the 1970s the US shopping mall was no longer just a solution to a problem, but also the potential cause of another in the form of an emergent 'donut' configuration of urban vitality and viability. This was typified by a 'dead' or hollow CBD with diminished retail provision, surrounded by a thriving 'edge city' (Garreau 1991). In this sense, the shopping mall is certainly symbolic of a fundamental spatial shift in the retail marketplace and associated consumption, as well as being a key factor in contributing to that shift.

Akin to Newton's third law, this decentralisation process emphasises how the creation of retail provision in one spatial context can be counterbalanced by its destruction elsewhere. It arguably creates a cycle of urban retail decline, which has inevitable consequences for associated marketplaces and their consumption activities. To clarify, the decentralisation narrative emphasised the retail plenitude, convenience and safety of the managed environment of the suburban mall. This stood in sharp contrast to the often denuded, inconvenient and unsafe retail environment of the urban core, causing it to be even less attractive due to a 'loss of a sense of place' (Oc and Tiesdell 1997), which itself could be partly attributed to retail decentralisation. The mall's apparent safety as space for consumption (at least compared to the urban core) was not without its critics. In fact, the idea was turned on its head in George A. Romero's 1978 film Dawn of the Dead. Survivors of an attack by flesh eating zombies hold out in a shopping mall, partaking of the abundant trappings of consumerism in abandoned stores, only to ultimately be attacked within the mall by the zombie undead. In this manner, Romero proposes a satirical and allegorical vision of the shopping mall as a space in which the consumer eventually becomes the consumed. This, therefore, is the shopping mall as an anti-marketplace icon, representing all that might be deemed wrong with capitalist modes of consumption: greed, a lack of community and cooperation, and a sense of individual gain and survival at the cost of others. Yet, most important in all of this, is the shopping mall's alluring consumer attraction - even to zombies. As two of the survivors comment when watching the zombies descend upon the mall from the vantage point of its roof:

Francine: "What are they doing? Why do they come here?"

Stephen: "Some kind of instinct. Memory of what they used to do. This was an important place in their lives." (YouTube clip 3 2009).

Although the suburban shopping mall and associated retail decentralisation may have created problems for urban centres, it is also worth noting that the construction of in-town and downtown 
shopping malls, particularly in the 1970 s and 1980s, was seen as a way to "staunch the haemorrhage of retail investment from the city centre" (Oc and Tiesdell 1997, 12) - thereby redefining one potential cause of an urban malaise to the role of a curative medicine. More recent attempts to reinstate the vitality and viability of urban cores are manifest in developments such as business improvement districts or BIDs (especially in North America and latterly in the UK), town centre management (particularly across Europe), and multifarious efforts at urban regeneration (many being retail-led). This leads to some interesting implications for the future of the shopping mall as a marketplace, which we discuss below.

\section{Malls and non-places}

A counter-narrative in research and wider commentary on the contemporary shopping mall is that it is the epitome of an anonymous 'blandscape'. Thus, instead of an "an idealised social space" (Goss, 1993, 24), or envisaged 'utopia of consumption' (Crawford 1992), defined in terms of a place which is perceived or imagined as perfect, what many regard as having actually emerged with the shopping mall is a utopia which corresponds more to the specific etymology of the term (i.e. from the Greek words meaning 'no-place'). Shopping malls have, consequently, been described by Goss (1993) as 'pseudoplaces', drawing on Wood's description of "places made over to be something they never were" $(1984,81)$. This is consistent with a notion of Disneyfication, whereby malls adopt strategies of dissemblance and duplicity to "manufacture the illusion that something else other than mere shopping is going on" (Goss 1993, 19). In this manner, the mall demonstrates many of the characteristics of 'placelessness' identified by Relph (1976), and 'non-places', as described by Augé (1996). Indeed, in this specific context, Jewell $(2001,335)$ notes that:

"The shopping mall, resolutely global in its underlying structure and ideological appeal, lacks the anthropological history and relational networks that Augé implies are the prerequisites of local identity necessary for the formation of 'place'. The shopping mall is seen instead as merely usurping the imagery that we associate with the values of place, as a means of subverting and concealing its dominant global values. By contriving a locality that in its material insubstantiality and its focus on transitory occupation is ultimately devoid of the values that supposedly constitute anthropological place, the mall is assigned by Augé and others the unenviable label of 'non-place'”.

These 'non-place' characteristics have undoubtedly been precipitated by designers removing from the mall those elements of the urban high street that are perceived to cause problems in the 'real world' of city and town centres, but which arguably give that world its character. Put otherwise, Goss (1993) argues the shopping mall is, to use de Certeau's (1984) term, a 'strategic space', in that it is owned and controlled by an institutional power, which inevitably depends on the definition, appropriation and control of territory. Those responsible for the management of malls will, therefore, often try to deny the possibility of what de Certeau terms 'tactics'; namely, an oppositional occupation by everyday practices (Goss 1993). 'Everyday practices' in this specific 
context could include taking photographs, loitering, as well as begging, busking or charity collections etc.

As noted above, the design of shopping malls can often be described as 'introverted', in the sense that they typically consist of inward-focused, boundaried and managed retail space. However, it is worth considering what happens when the urban high street (or streets) becomes the site of new forms of shopping mall development. Thus, whilst the stereotype of the shopping mall locates it in an out-of-town, suburban location - a concrete island, surrounded by a sea of car parking spaces we should not forget that the various types of malls which Coleman (2006) suggests constitute 'town centre shopping' have an obvious impact on the towns and cities within which they are located. One of the more recent developments in this respect has been the creation of a more 'extroverted' mall design in the form of what have been termed 'malls without walls'. Here, previously public space, such as the urban high street, is annexed by private sector commercial interests for the purposes of maximising retail consumption. Minton (2009) describes this process using the specific example of Liverpool One, a retail-led development of 42 acres of Liverpool city centre encompassing 34 streets, which through the use of 'public realm arrangements' has removed public rights of way in some areas of the city. Liverpool One is, at the time of writing, the largest of these "open air property complexes which also own and control the streets, squares and open spaces of the city" (ibid., 15), and there are some obvious parallels between this development and the higher profile and more successful BIDs that have been introduced in North America to revitalise enclaves of urban retailing space.

Such developments have not been without criticism: both in terms of the alleged privatisation of public space (see Kingsnorth 2008), and also regarding the implications for place identity and nonplaces. As Minton $(2009,34)$ notes:

“...when I went there [Liverpool One] I found that despite the relatively interesting architecture, there was nothing about the place to remind me of where I actually was - I could have been anywhere in Britain or America with a high-end shopping centre with hundreds of upmarket shops. The careful branding of the bins, benches and bollards dividing the complex from the rest of the city kept reminding me I was in Liverpool One, as did the uniforms of the private-security guards and cleaners, but although I had been told that the design of the complex faithfully followed the original street pattern, I couldn't see any street signs".

\section{Some final thoughts...}

The above discussion raises some significant implications regarding the contemporary role of the shopping mall as a site of consumption. Recent years have witnessed a general trend towards the experiential in retailing (see for example, Antéblian, Filser and Roederer 2014; Verhoef, Lemon, Parasuraman, Roggeveen, Tsiros and Schlesinger 2009). Indeed, a report by the British Council of Shopping Centres (BCSC) titled Future of Retail Property notes that "customer 'experience' is the new battleground. Shopping must not be bland and uneventful, but rather an efficient, exciting and emotionally engaging episode" (BCSC 2007, 10-12), and goes on to state that shopping places, 
"must aspire to greater authenticity and re-enchantment of place and identity to create emotionally responsive and desirable environments" (ibid., 7). However, there is a potential paradox in that these "emotionally responsive" environments might be regarded as inauthentic non-places. The increasing ubiquity of the multiple retailer, not only in shopping malls (in many cases, they are the only companies who can afford the rental costs of the space therein), but also in unplanned urban high street shopping destinations, has further highlighted this point - in the UK context, the consequent loss of local identity has been described in terms of a 'clone town Britain' (see New Economics Foundation 2004).

In those instances where the shopping mall is presented as hyper-real utopia of the urban retail experience, it is not surprising that there have been attempts to reframe such malls as potentially being the cores of new towns (see Lowe 2000), resonating with Gruen's original vision of shopping malls as centres of community within a locale. In the UK, for example, there have been moves (albeit, to date, unsuccessful) to officially recast some regional shopping centres (RSCs - the UK version of US mega-malls) as town centres. As Lowe $(2000,273)$ states:

"...no-one would argue that Merry Hill, the Metrocentre, Meadowhall or Cribbs Causeway [i.e. major RSCs] are finished 'urban forms', yet these centres are likely to have a considerable impact on Britain's urban futures into the $21^{\text {st }}$ century and beyond... whatever our prejudices, it is surely now time to take these new urban forms seriously".

In the intervening period since Lowe's discussion, the trend towards the blurring of distinctions between public and private space, through the development in urban centres of 'malls without walls' (outlined above), has arguably created another trajectory where these hybrid consumption spaces assume even greater importance in the retail and consumption landscape. This emphasises that the shopping mall, as a marketplace icon, continues to dynamically and iteratively define and refine the ongoing interactions between consumers, the act of consumption, and place and space. 


\section{References}

Antéblian, Blandine, Marc Filser and Claire Roederer. 2013. "Consumption experience in retail environments: A literature review." Recherche et Applications en Marketing (English Edition), 28 (3): 82-109.

Augé, Marc. 1995. Non-Places: Introduction to an Anthropology of Supermodernity, (Trans. J. Howe), London and New York: Verso.

Bonnett, Alastair. 2014. Off the Map: Lost Spaces, Invisible Cities, Forgotten Islands, Feral Places, and What They Tell Us About the World. London: Aurum Press.

British Council of Shopping Centres [BCSC]. 2007. Future of Retail Property: Future Shopping Places. London: British Council of Shopping Centres.

Butler, R. W. 1991. "West Edmonton Mall as a tourist attraction." The Canadian Geographer/Le Géographe Canadien, 35 (3): 287-295.

Carcopino, Jerome. 1991 [1941]. Daily Life in Ancient Rome -The People and the City at the Height of the Empire. London: Penguin Books.

Coleman, Peter. 2006. Shopping Environments: Evolution, Planning and Design. Oxford: Architectural Press.

Crawford, Margaret. 1992. "The world in a shopping mall." In Variations on a Theme Park: The New American City and the End of Public Space, edited by Michael Sorkin, 3-30. New York: Hill and Wang.

Crossick Geoffrey and Serge Jaumain. Eds. 1999. Cathedrals of Consumption: The European Department Store, 1850-1939. Aldershot: Ashgate.

de Certeau, Michel. 1994. The Practice of Everyday Life. Berkeley, Los Angeles, London: University of California Press.

Dennis, Charles with Andrew Newman and David Marsland. 2009. Objects of Desire: Consumer Behaviour in Shopping Centre Choices. Basingstoke: Palgrave Macmillan.

Finn, Adam and Tulin Erdem. 1995. "The economic impact of a mega-multi-mall: estimation issues in the case of West Edmonton Mall." Tourism Management, 16 (5): 367-373.

Garreau, Joel. 1991. The Edge City: Life on the New Frontier. New York: Doubleday.

Gerlach, Jerry and James Janke. 2001. "The mall of America as a tourist attraction." Focus on Geography, 46 (3): 32-36.

Geist, Johann Friedrich. 1989. Arcades - The History of a Building Type. Cambridge MA: MIT Press Goffin, Gerry and Carole King. 1967. Pleasant Valley Sunday. Song originally written for The Monkees. 
Goss, Jon. 1993. "The "Magic of the Mall": An analysis of form, function, and meaning in the contemporary retail built environment." Annals of the Association of American Geographers, 83 (1): $18-47$

Goss, Jon. 1999. "Once-upon-a-time in the commodity world: An unofficial guide to the Mall of America." Annals of the Association of American Geographers, 89 (1): 45-75.

Gladwell, Malcolm. 2004. "The terazzo jungle: Fifty years ago the mall was born. America would never be the same." The New Yorker, Annals of Commerce, March 15, http://www.newyorker.com/magazine/2004/03/15/the-terrazzo-jungle

Gruen, Victor. 1960. Shopping Towns USA. New York: Van Nostrand Reinhold Company. (Cited in Jewell, 2001).

Guy, Clifford. 1994. The Retail Development Process: Location, Property and Planning. London: Routledge.

Hobsbawm, Eric. 1989. Age of Empire: 1875-1914. London: Abacus.

Hopkins, Jeffrey. 1990. "West Edmonton Mall: landscape of myths and elsewhereness." The Canadian Geographer/Le Géographe Canadien, 34 (1), 2-17.

Hopkins, Jeffrey. 1991. "West Edmonton Mall as a centre for social interaction." The Canadian Geographer/Le Géographe canadien, 35 (3): 268-279.

Jackson, Edgar L. 1991. "Shopping and leisure: Implications of West Edmonton Mall for leisure and for leisure research." The Canadian Geographer/Le Géographe canadien, 35 (3): 280-287.

Jackson, Peter and Nigel Thrift. 1995. "Geographies of consumption." In Acknowledging Consumption: A Review of New Studies, edited by Daniel Miller, 204-237. London and New York: Routledge.

Jewell, Nicholas. 2001. "The fall and rise of the British mall." The Journal of Architecture, 6 (4): 317378.

Kingsnorth, Paul. 2008. Cities for Sale. The Guardian, 29 March, http://www.theguardian.com/society/2008/mar/29/communities

Kowinski, William Severini. 1985. The Malling of America: An Inside Look at the Great Consumer Paradise. New York: William Morrow and Company.

Lowe, Michelle. 2000. Britain's regional shopping centres: New urban forms? Urban Studies, 37 (2): 261-274.

MacKeith, Margaret. 1986. The History and Conservation of Shopping Arcades. London and New York: Mansell Publishing.

Minton, Anna. 2009. Ground Control: Fear and Happiness in the Twenty-First Century City. London: Penguin Books. 
Nava, Mica. 1996. "Modernity's disavowal: Women, the city and the department store'". In Modern Times: Reflections on a Century of English Modernity, edited by Mica Nava and Alan O'Shea, 38-76. Abingdon and New York: Routledge.

New Economics Foundation. 2004. Clone Town Britain: The Loss of Identity on the nation's High Streets. London: New Economics Foundation.

Oc, Taner and Steven Tiesdell. 1997. "The death and life of city centres." In Safer City Centres: Reviving the Public Realm, edited by Taner Oc and Steven Tiesdell, 1-20. London: Paul Chapman Publishing Ltd.

Relph, Edward. 1976. Place and Placelessness. London: Pion.

Said, Sammy. 2013 "The top ten biggest malls in the world." The Rchest, www.therichest.com/richlist/nation/the-top-10-biggest-malls-in-the-world/.

Schiller, Russell. 1986. "Retail decentralisation: the coming of the third wave." The Planner, 72 (7): 13-15.

Schumpeter, Joseph. 1942. Socialism, Capitalism and Democracy. New York: Harper and Brothers.

Shields, R. 1989. "Social spatialization and the built environment: the West Edmonton Mall." Environment and Planning D: Society and Space, 7 (2), 147-164.

Smyth, H. 1994. Marketing the City: The Role of Flagship Developments in Urban Regeneration. London: E \& F N Spon.

Verhoef, Peter C., Katherine N. Lemon, A. Parasuraman, Anne Roggeveen, Michael Tsiros and Leonard A. Schlesinger. 2009. „Customer experience creation: Determinants, dynamics and management strategies." Journal of Retailing, 85 (1): 31-34.

Wood, Joseph S. 1984. "Nothing should stand for something that never existed." Places 2 (2): 81-87. YouTube clip 1. (2014). A brief history of the American shopping mall, https://www.youtube.com/watch?v=hcWcspY59HM

YouTube clip 2. (2013). 12 Days of Minnesota Christmas: At Southdale, the classic shopping mall is born, https://www.youtube.com/watch?v=gBFDCHdO27Q

YouTube clip 3. (2009). Dawn of the Dead (1978) First Mall Scene, https://www.youtube.com/watch?v=7zK_44APmbY 